\title{
The Bactericidal Effect of High Temperature Is an Essential Resistance Mechanism of Chicken Macrophage against Brucella abortus Infection
}

\author{
Lauren Togonon Arayan, Alisha Wehdnesday Bernardo Reyes, Huynh Tan Hop, Huy Tran Xuan, Eun Jin Baek, \\ Wongi Min, and Suk Kim*
}

Institute of Animal Medicine, College of Veterinary Medicine, Gyeongsang National University, Jinju 52828, Republic of Korea

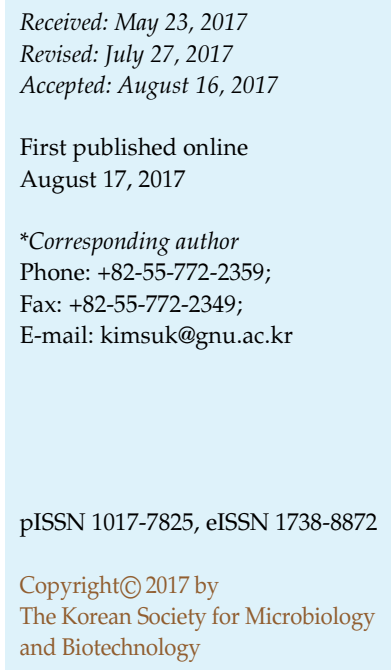

Knowledge of avian host responses to brucellosis is critical to understanding how birds resist this infection; however, this mechanism is not well established. On the other hand, temperature has a major involvement in the physiology of living organisms, and cell death induced by heat is attributed to protein denaturation. This study demonstrates the direct bactericidal effect of a high temperature $\left(41^{\circ} \mathrm{C}\right)$ on Brucella abortus that resulted in the gradual reduction of intracellular bacteria and inhibited bacterial growth within avian macrophage HD11 in an increasing period of time. On the other hand, this study also revealed that high temperature does not affect the rate of bacterial uptake, as confirmed by the bacterial adherence assay. No significant difference was observed in the expression of target genes between infected and uninfected cells for both temperatures. This study suggests the susceptibility of $B$. abortus to bacterial death under a high temperature with an increased period of incubation, leading to suppression of bacterial growth.

Keywords: B. abortus, avian macrophage, bactericidal effect, body temperature

\section{Introduction}

Innate and adaptive immune host responses are critical into the understanding of how certain species resist certain diseases. However, the molecular basis of Brucella and chicken host interaction is not well elucidated to date [1]. Innate resistance to diseases involves a complex process that could be due to an inherent multigenic trait characterized in a particular species [2]. On the other hand, temperature is highly involved in an array of intricate physiologic activities throughout evolution [3]. High body temperature has precluded the occurrence of several infectious diseases in avian species. For example, Blackleg disease in cattle is prevented in poultry owing to this temperature difference [4]. It has been demonstrated that hyperthermia can reduce the proliferation of pathogens, specifically bacteria, which can be considered a major advantage to the host. It has long been recognized that birds would respond to infectious agents with a significant increase in the core body temperature [5]. Researchers have utilized lipopolysaccharide (LPS) as the most common form of pathogen-associated molecular patterns to trigger the immune system and to investigate the dynamics of hyperthermia in this species [5]. Phagocytic activity is considered one of the most important conserved evolutionary functions. Specific receptors are present on the surface of avian macrophages essential for the uptake of bacteria as well as receptors intended to mediate activation signals for LPS-binding receptors, including mannose, Fc receptors, as well as scavenger receptors [6]. Although disease resistance to various infectious agents has been recognized as a multifaceted trait in avian species, the precise pathogenic and resistance mechanisms of avian brucellosis are not yet understood.

Several insights into the relationship of temperature with bacterial replication have been explored [3]. A number of studies relating to thermal adaptation being dependent on protein stability in relation to temperature have provided sufficient data indicating that bacterial growth is precipitously diminished upon increasing temperature [7, 8]. Optimal bacterial growth is achieved only when products of ratedetermining proteins are intact. In one study, the effect of 
temperature was evaluated on the functionality of proteins that are responsible for replication and concluded that a high temperature causes a significant decrease of folded or functional rate-determining protein, leading to inhibition of bacterial growth [3]. On the extreme end, the lethal denaturation temperature was also determined when bacterial proteins were denatured upon incubation with higher temperature in reference to $37^{\circ} \mathrm{C}$, which is considered to be an original evolutionary temperature [3].

The goal of this study was to determine the effect of temperature directly on Brucella abortus and in chicken macrophages incubated at a normothermic temperature of $37^{\circ} \mathrm{C}$ and a higher temperature of $41^{\circ} \mathrm{C}$, in relation to the bacterial invasion and intracellular replication of B. abortus that would likely simulate the mammalian and avian general core body temperature, respectively. In addition, we assessed the immune response by assessing the expression of chicken proinflammatory cytokines, such as IL-1 $\beta$, IL-6, and IFN- $\alpha$, in $B$. abortus-infected and uninfected cells through the use of quantitative RT-PCR.

\section{Materials and Methods}

\section{Bacteria and Cell Cultures}

Standard wild-type strains were derived from B. abortus 544 (ATCC 23448), a smooth, virulent B. abortus biovar 1 strain. The B. abortus strain was cultivated in Brucella broth or on Brucella agar. Bacteria were grown at $37^{\circ} \mathrm{C}$ with vigorous shaking until they reached the stationary phase. HD11 cells, an avian macrophage cell line established according to a previously reported method [9], were maintained in Dulbecco's modified Eagle's medium (DMEM) containing 10\% heat-inactivated fetal bovine serum and antibiotics $(100 \mathrm{U} / \mathrm{ml}$ penicillin and $100 \mu \mathrm{g} / \mathrm{ml}$ streptomycin) (Gibco, USA) at $37^{\circ} \mathrm{C}$ and $41^{\circ} \mathrm{C}$ at $5 \% \mathrm{CO}_{2}$ atmosphere.

\section{Bactericidal Analysis}

Bacteria were diluted with PBS to a concentration of $2 \times 10^{4}$ colony forming units $(\mathrm{CFU}) / \mathrm{ml}$, and incubated at $37^{\circ} \mathrm{C}$ or $41^{\circ} \mathrm{C}$ for 0, 4, 24, 48, and $72 \mathrm{~h}$. Each diluent was plated onto Brucella agar and incubated for 2 days at $37^{\circ} \mathrm{C}$. The bacterial survival rates were expressed as the percentage of the survival of the sample incubated at $41^{\circ} \mathrm{C}$ relative to the control that was incubated at $37^{\circ} \mathrm{C}$ and set at $100 \%$ [10].

\section{Cytotoxicity Assay}

The cytotoxic effect of temperature at $37^{\circ} \mathrm{C}$ and $41^{\circ} \mathrm{C}$ was evaluated by 3-(4,5-dimethylthiazol-2yl)-2,5-diphenyl-2H-tetrazolium bromide (MTT) assay. Furthermore, to evaluate the cytotoxicity of temperature with infection in $\mathrm{HD} 11$, overnight culture at $37^{\circ} \mathrm{C}$ and $41^{\circ} \mathrm{C}$ in 96 -well plates at $2 \times 10^{4}$ cells/well were infected with B. abortus at a multiplicity of infection (MOI) of 10 , and then centrifuged at $150 \times g$ for $10 \mathrm{~min}$ at room temperature. The infected cells were washed once with PBS and then incubated at $37^{\circ} \mathrm{C}$ and $41^{\circ} \mathrm{C}$ with DMEM containing $10 \%$ (v/v) FBS and gentamicin $(30 \mu \mathrm{g} / \mathrm{ml})$ for $30 \mathrm{~min}$ to kill any remaining extracellular bacteria, and then incubated at $37^{\circ} \mathrm{C}$ and $41^{\circ} \mathrm{C}$ in $5 \% \mathrm{CO}_{2}$ for $4,24,48$, and $72 \mathrm{~h}$. At the end of each incubation, the cytotoxic effect was evaluated using MTT assay [11]. The viability rate of infected HD11 was expressed as the percentage of the absorbance of the sample relative to uninfected cells incubated at $37^{\circ} \mathrm{C}$ at $0 \mathrm{~h}$, which was set at $100 \%$.

\section{Determination of Uptake and Survival of B. abortus in Chicken Macrophages}

HD11 cells, overnight culture in 96-well plates at $2 \times 10^{4}$ cells/well, were infected with $B$. abortus. The bacteria were then deposited onto the cells at a MOI of 100 , centrifuged at $150 \times g$ for $10 \mathrm{~min}$ at room temperature, and incubated at $37^{\circ} \mathrm{C}$ or $41^{\circ} \mathrm{C}$ in $5 \% \mathrm{CO}_{2}$ for 0 , 15 , and $30 \mathrm{~min}$. The infected cells were washed once with PBS and then incubated at $37^{\circ} \mathrm{C}$ or $41^{\circ} \mathrm{C}$ in DMEM containing $10 \%$ FBS and gentamicin $(30 \mu \mathrm{g} / \mathrm{ml})$ for $30 \mathrm{~min}$. The cells were washed twice with PBS and lysed with distilled water. For test of intracellular growth efficiency, bacterial infection was done as described above for bacterial internalization. Infected cells were incubated for 2, 24, and $48 \mathrm{~h}$ with DMEM containing 10\% FBS and gentamicin ( $30 \mu \mathrm{g} / \mathrm{ml})$. The same protocol for washing, lysis, and plating was conducted to analyze the efficiency of bacterial internalization as conducted according to a previously reported method [12].

\section{Bacterial Adherence Assay}

HD11 cells were cultured in 12-well plates in $18 \mathrm{~mm}$ glass coverslips, incubated overnight at $37^{\circ} \mathrm{C}$ or $41^{\circ} \mathrm{C}$. Cells were treated with a final concentration of $1.25 \mu \mathrm{g} / \mathrm{ml}$ cytochalasin D by adding $2.5 \mu \mathrm{l}(500 \mu \mathrm{g} / \mathrm{ml})$ to inhibit bacterial internalization $40 \mathrm{~min}$ prior to infection. Cells were infected with an MOI of 10 for $30 \mathrm{~min}$, fixed with $4 \%$ paraformaldehyde and incubated at $37^{\circ} \mathrm{C}$ for $1 \mathrm{~h}$, then permeabilized with $0.1 \%$ Triton $\mathrm{X}-100$ at $22^{\circ} \mathrm{C}$ for $10 \mathrm{~min}$ followed by incubation with blocking buffer ( $2 \%$ goat serum in PBS) for $30 \mathrm{~min}$. A series of further incubation with anti-B. abortus polyclonal rabbit serum in blocking buffer and fluorescein isothiocyanate-conjugated goat anti-rabbit immunoglobulin G (IgG) (Sigma-Aldrich, USA) in blocking buffer at $37^{\circ} \mathrm{C}$ for $1 \mathrm{~h}$ were conducted. The coverslips were washed and mounted with a fluorescent solution. A laser scanning microscope (FV1000; Olympus, Japan) was used to capture the fluorescence images. One hundred macrophages were chosen randomly and adhered bacteria were counted [10].

\section{Intracellular Bacterial Staining}

Intracellular bacterial staining was conducted with slight modification [10]. HD11 cells incubated at $37^{\circ} \mathrm{C}$ or $41^{\circ} \mathrm{C}$ overnight were infected for $1 \mathrm{~h}$ at $37^{\circ} \mathrm{C}$ or $41^{\circ} \mathrm{C}$, washed with medium, and further incubated in DMEM containing 10\% FBS and gentamicin $(30 \mu \mathrm{g} / \mathrm{ml})$ for 24 and $48 \mathrm{~h}$ for both temperatures. Fixation, 
permeabilization, and blocking protocols were conducted as with the bacterial adherence assay. Fluorescence images were processed with FV10-ASW Viewer 3.1 software. One hundred macrophages were chosen randomly and intracellular bacteria were counted. The total number of intracellular bacteria in 100 random macrophages incubated at $37^{\circ} \mathrm{C}$ was set at $100 \%$.

\section{RNA Extraction and cDNA Synthesis}

HD11 cells at $2 \times 10^{6}$ cells/well in 6-well culture plates were cultured overnight at $37^{\circ} \mathrm{C}$ or $41^{\circ} \mathrm{C}$ at $5 \% \mathrm{CO}_{2}$. The cells were infected with B. abortus at a MOI of 10, centrifuged at $150 \times g$ for $10 \mathrm{~min}$ at room temperature, and incubated at $37^{\circ} \mathrm{C}$ or $41^{\circ} \mathrm{C}$ in $5 \%$ $\mathrm{CO}_{2}$ for $30 \mathrm{~min}$. The infected cells were washed once with PBS and then incubated at $37^{\circ} \mathrm{C}$ or $41^{\circ} \mathrm{C}$ at $5 \% \mathrm{CO}_{2}$ in DMEM containing $10 \% \mathrm{FBS}$ and gentamicin $(30 \mu \mathrm{g} / \mathrm{ml})$ at indicated times $(12,24$, and $48 \mathrm{~h}$ ) prior to total RNA harvest. Total RNA was extracted from HD11 cells with the use of RiboEx reagent (Geneall, South Korea) and a commercially available reagent RNeasy Mini kit (Qiagen, Germany) [13]. To remove any contaminating genomic DNA, the sample was treated with RNase-free DNase I (Qiagen, Korea). Purified RNA was eluted in $15 \mu$ l of RNase-free water and stored at $-70^{\circ} \mathrm{C}$. Total RNA was measured using a spectrophotometer (Optizen, Korea). Single stranded cDNA was synthesized from 1-2 $\mu$ g of total RNA using a Quantitect Reverse Transcription Kit (Qiagen, Hilden, Germany) following the manufacturer's instructions.

\section{Real-Time RT-PCR}

Real-time RT-PCR was performed in duplicate using a CFX96 real-time RT-PCR system (Bio-Rad, USA) with SYBR Green (Bioneer, Korea). Expression levels of target genes were determined using the following primers: IL-1 $\beta$ forward 5'-TGGGCATCAAGGGCTACA-3', reverse $5^{\prime}$-TCGGGTTGGTTGGTGATG-3'; IFN- $\alpha$ forward $5^{\prime}$-GAC ATCCTTCAGCATCTCTTCA- $3^{\prime}$, reverse $5^{\prime}$-AGGCGCTGTAAT CGTTGTCT-3' [14]; and IL-6 forward 5'-GCGAGAACAGCA TGGAGATG-3', reverse 5'-GTAGGTCTGAAAGGCGAACAG-3' [15]. Gene expression levels were quantified using $\Delta \Delta C_{t}$ [16]. A melting curve was obtained at the end of each run to rule out the presence of primer dimers. $\beta$-Actin (primers, forward $5^{\prime}$-CAC AGATCATGTTTGAGACCTT- $3^{\prime}$ and reverse $5^{\prime}$-CATCACAAT ACCAGTGGTACG-3') was used as the reference gene to normalize the relative expression levels of individual transcripts with the use of Bio-Rad CFX software.

\section{Statistical Analysis}

Gathered data were statistically analyzed using Student's $t$-test or one-way ANOVA, using Instat software (GraphPad, USA), followed by Dunnet's multiple comparison test. The mRNA levels were analyzed using Mann-Whitney, Kruskal-Wallis, and Dunn's multiple comparison tests. Data were considered statistically significant at $p<0.05$. Data were expressed as the mean \pm standard error (SE).

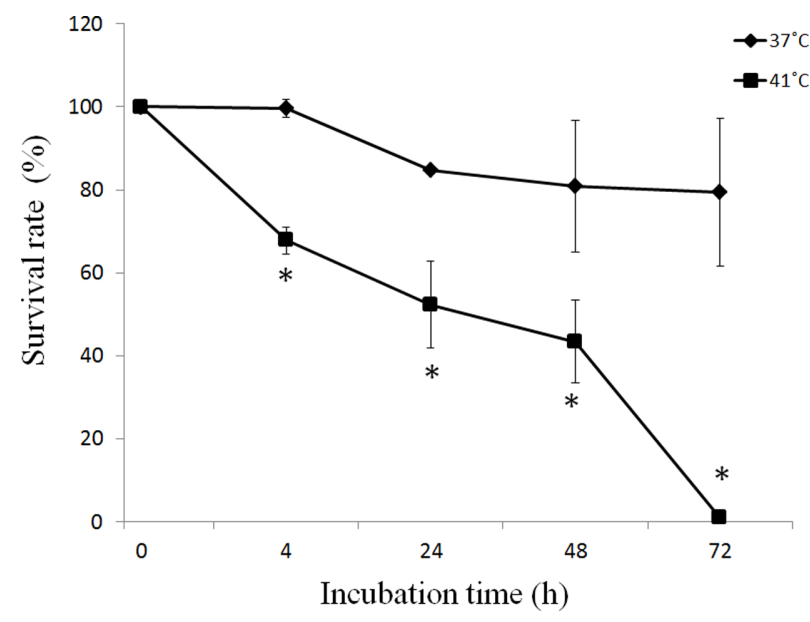

Fig. 1. Determination of the effect of temperature on B. abortus and HD11 cells.

Bactericidal effect of temperature at specified time points. Bacterial viability was assessed through $\mathrm{CFU}$ counting on culture plates, and the rate of bacterial viability was compared with the zero time point at $37^{\circ} \mathrm{C}$ (Control). Data represent the mean $\pm \mathrm{SD}$ of triplicate samples from three identical experiments. Statistically significant difference relative to control is indicated by an asterisk $(*, p<0.05)$.

\section{Results}

\section{Bactericidal and Cytotoxicity Assays}

Evaluation of bacterial viability at $37^{\circ} \mathrm{C}$ and $41^{\circ} \mathrm{C}$ resulted in a significant difference in bacterial viability at the 0,4 , 24,48 , and $72 \mathrm{~h}$ time points. Incubation at $41^{\circ} \mathrm{C}$ markedly resulted in decreased bacterial CFU count with viability of $67.84 \%, 52 \%, 43.41 \%$, and $1 \%$ at $4,24,48$, and $72 \mathrm{~h}$, respectively, as opposed to incubation at $37^{\circ} \mathrm{C}$ with viability of $99.74 \%, 84.72 \%, 80.84 \%$, and $79.49 \%$ at $4,24,48$, and $72 \mathrm{~h}$, respectively $(p<0.05)$ (Fig. 1). On the other hand, evaluation on the cytotoxicity of temperature on HD11 was found to have no difference between incubation at $37^{\circ} \mathrm{C}$ and $41^{\circ} \mathrm{C}$ in both uninfected (Fig. 2A) and infected cells (Fig. 2B).

\section{Determination of Uptake and Survival of B. abortus in Chicken Macrophages}

The results indicated that B. abortus invasion at $41^{\circ} \mathrm{C}$ was not significantly different at 0,15 , and $30 \mathrm{~min}$ post-infection (Fig. 3A). In the intracellular survival assay, intracellular replication was significantly reduced by $51 \%$ and $59 \%$ at 24 and $48 \mathrm{~h}$, respectively, while no bacterial growth was observed at $72 \mathrm{~h}$ incubation (Fig. 3B). The intracellular bacterial load was significantly decreased according to the 

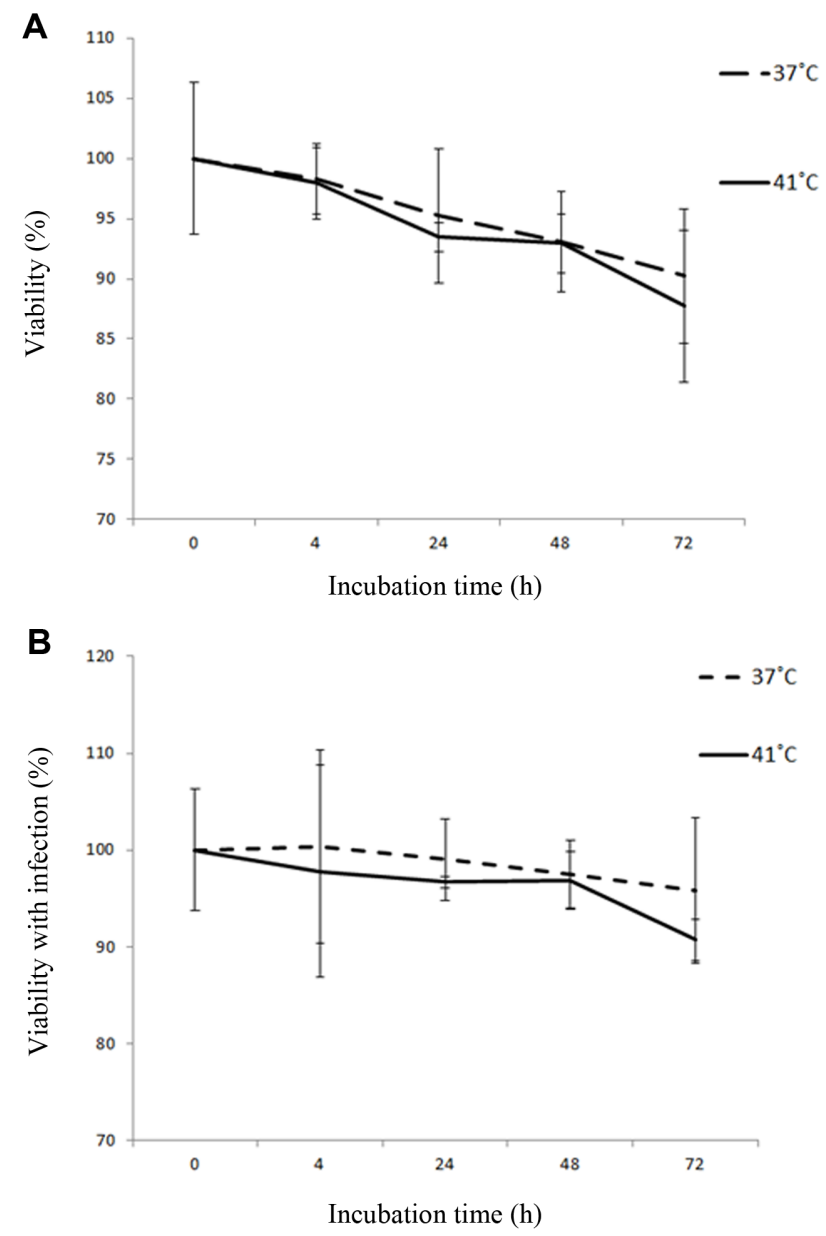

Fig. 2. Determination of the effect of temperature on HD11.

(A) Viability of HD11 upon incubation at 0, 4, 24, 48, and $72 \mathrm{~h}$. (B) Viability of HD11 after infection with B. abortus at 0, 4, 24, 48, and $72 \mathrm{~h}$ using the MTT assay. Data represent the mean \pm SD of triplicate samples from three identical experiments. Statistically significant difference relative to control $\left(37^{\circ} \mathrm{C}\right)$ is indicated by asterisk $\left({ }^{*}, p<0.05\right)$.

relative bactericidal effect of temperature at $41^{\circ} \mathrm{C}$. Incubation at $37^{\circ} \mathrm{C}$, however, was able to retain a very slow intracellular growth.

\section{Bacterial Adherence Assay and Intracellular Bacterial Staining}

Quantification of adhered bacteria showed no difference in cells incubated at $37^{\circ} \mathrm{C}$ and $41^{\circ} \mathrm{C}$. However, there was significant reduction in the number of intracellular bacteria in cells incubated at $41^{\circ} \mathrm{C}$ after 24 and $48 \mathrm{~h}$ incubation (Figs. 4A-4D).

\section{Real-Time RT-PCR}

Relative mRNA expression levels of IL-1 $\beta$, IL-6, and IFN-
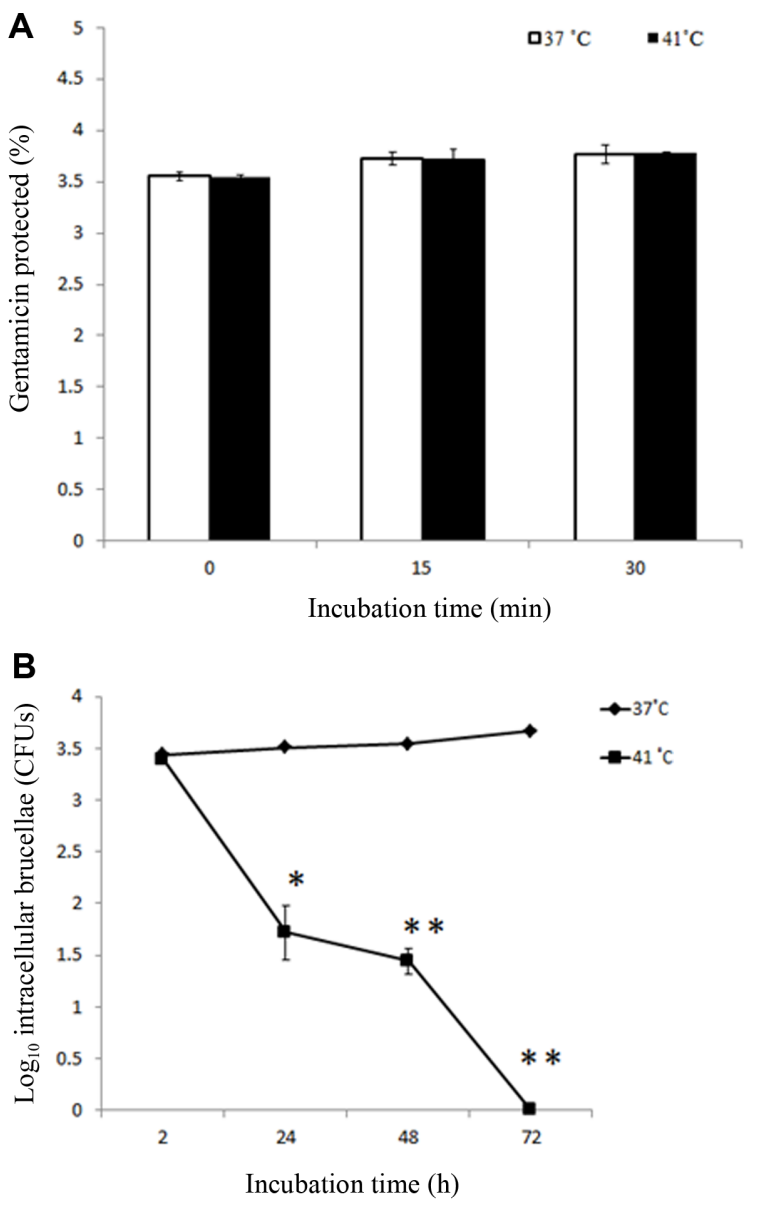

Fig. 3. Effect of temperature on bacterial uptake and intracellular survival within macrophages.

After bacterial infection, (A) bacterial internalization and (B) intracellular growth of $B$. abortus in HD11 macrophages were evaluated. Data represent the mean \pm SD of triplicate samples from three identical experiments. Statistically significant difference relative to control $\left(37^{\circ} \mathrm{C}\right)$ is indicated by asterisks $\left({ }^{*}, p<0.01 ;{ }^{* *}, p<0.001\right)$. Values represent the means of three identical experiments performed in triplicate; error bars indicate SD.

$\alpha$ were evaluated at $37^{\circ} \mathrm{C}$ and $41^{\circ} \mathrm{C}$, at time points 12,24 , and $48 \mathrm{~h}$. This study demonstrated that there was no significant difference in the levels of expression among the cytokines in the presence or absence of Brucella infection. However, there was slight increase in the expression of these cytokines in cells at $41^{\circ} \mathrm{C}$, particularly IL-1 $\beta$ at $24 \mathrm{~h}$ with or without infection.

\section{Discussion}

High Brucella antibody titers in birds indicate that natural 


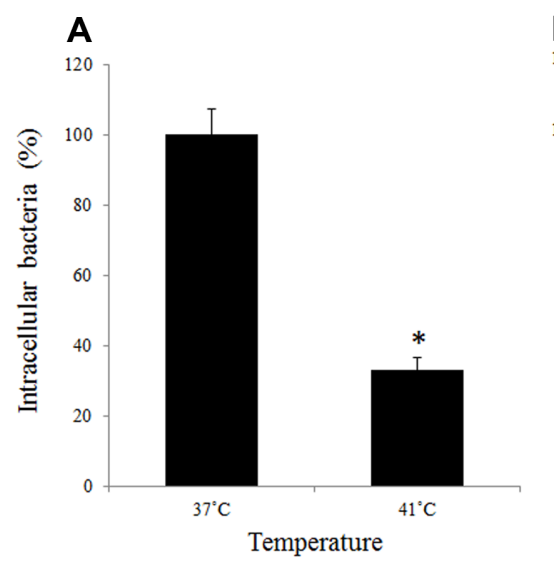

C

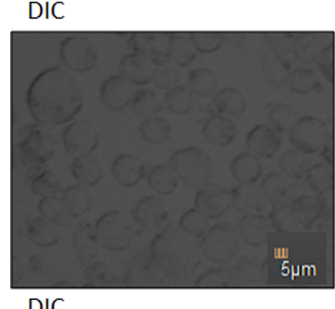

DIC

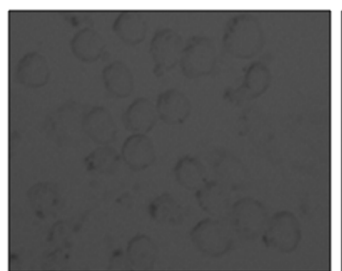

Brucella abortus, $37^{\circ} \mathrm{C}$

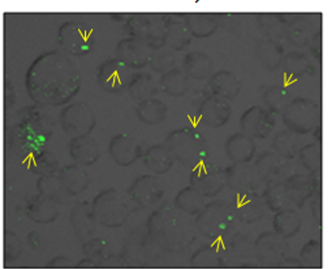

Brucella abortus, $41^{\circ} \mathrm{C}$

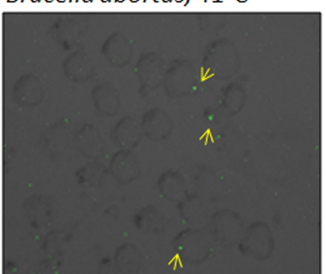

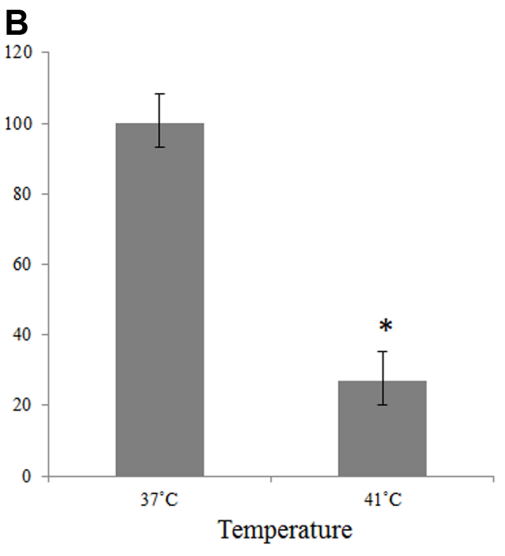

D

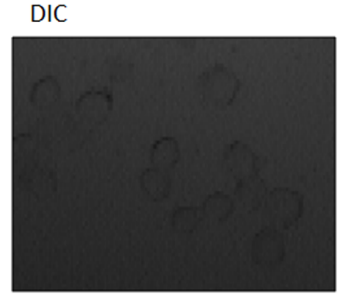

DIC

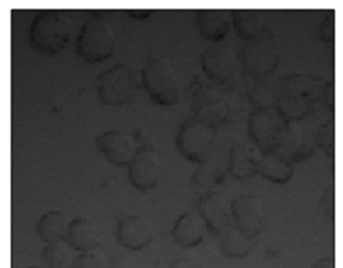

Brucella abortus, $37^{\circ} \mathrm{C}$

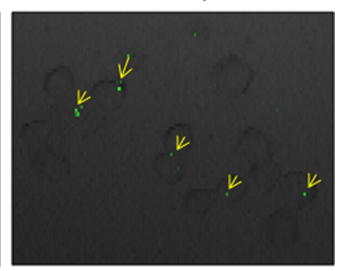

Brucella abortus, $41^{\circ} \mathrm{C}$

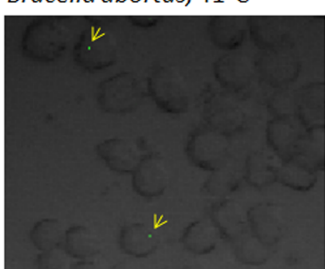

Fig. 4. Staining and quantification of intracellular bacteria under the different temperatures.

The total number of intracellular bacteria in 100 random macrophages incubated at $37^{\circ} \mathrm{C}$ or $41^{\circ} \mathrm{C}$ after $24(\mathbf{A}, \mathbf{C})$ and $48 \mathrm{~h}(\mathbf{B}, \mathbf{D})$ post-infection was counted, where the bacterial number of $37^{\circ} \mathrm{C}$ incubation was set at $100 \%$. Representative images of intracellular bacteria are shown in arrows. Statistically significant difference relative to control $\left(37^{\circ} \mathrm{C}\right)$ is indicated by the asterisk $\left({ }^{*}, p<0.001\right)$. Values represent means of three identical experiments performed in triplicate; error bars indicate $\mathrm{SD}$.

infection can occur through exposure to the primary hosts of Brucella, but this exposure does not necessarily lead to chronic infection. Birds are also able to shed the organism in their droppings, making them a reservoir and potential risk for humans [17]. In this study, we utilized HD11, a chicken macrophage-like cell line that has been recognized to highly express cell surface antigens, $\mathrm{F}_{\mathrm{c}}$ receptors, and exhibit phagocytic activity [9]. The phagocytic system is activated at the early chick embryonic life, but certain factors may influence the increased age-related resistance of embryos to B. abortus [18]. Interestingly, after hatching, chicks become highly resistant to $B$. abortus and are able to eliminate the infection in a matter of weeks [18].

We compared and simulated the effect of a major physiological variation of birds over mammals, which is core body temperature, through the use of HD11 in vitro.
B. abortus is a mesophilic bacterium that grows at $37^{\circ} \mathrm{C}$ optimum temperature, although this could range from $20^{\circ} \mathrm{C}$ to $40^{\circ} \mathrm{C}$ and even up to $44^{\circ} \mathrm{C}$ [19].

In this study, B. abortus was shown to be increasingly sensitive to a higher temperature over an extended period of time. In the bactericidal assay, incubation of B. abortus at $41^{\circ} \mathrm{C}$, at 24 to $48 \mathrm{~h}$ time points, rendered about $50 \%$ lethality, and was absolutely bactericidal at $72 \mathrm{~h}$ relative to the control incubated at $37^{\circ} \mathrm{C}$. Several studies, including Chen and Shakhnovich [3], have elucidated the effect of higher temperature on the viability and ability of prokaryotes to replicate. Higher temperature has a great impact on bacterial protein stability and its ability to replicate and survive. The unfolding of key proteins due to thermal changes can lead to a lethal phenotype [20]. The importance of proteins being able to maintain their native 
conformation (folded state) is essential for them to be functional [21-24]. Another interesting study by Leuenberger et al. [25] laid out massive data on the protein thermostability of about 8,000 proteins of organisms subjected to different high temperatures, including the bacterium Escherichia coli, using a proteomic strategy. Their study concluded that important protein subgroups with essential functions on cells are lost owing to denaturation leading to cellular disintegration in cells subjected to high temperatures [25]. Although there are no literatures that we know of regarding Brucella and its thermal adaptation, these previous studies give insight into the lethal susceptibility of $B$. abortus to higher temperatures, as manifested in the bactericidal assay.

HD11 is an avian macrophage that has been routinely incubated at $41^{\circ} \mathrm{C}$ as with other studies [26]. Consistent with this, our data also showed that this high temperature did not cause significant host cell death in comparison with host cells incubated at $37^{\circ} \mathrm{C}$ for both infected or uninfected cells.

For internalization, there was no observed difference among all the time points for both temperatures. Thus, receptors on macrophages responsible for bacterial invasion may not be affected by the difference in temperature. To confirm the result for the rate of internalization, we conducted a bacterial adherence assay and concluded that the number of attached bacteria was not significantly different in cells incubated either at $37^{\circ} \mathrm{C}$ or $41^{\circ} \mathrm{C}$. This result is consistent with one of our unpublished studies on murine macrophage RAW264.7.

The intracellular survival assay showed significant decline in the intracellular growth of B. abortus at $41^{\circ} \mathrm{C}$ and might be attributed to the bactericidal effect of temperature. To prove this, we analyzed the percentage of intracellular bacteria through microscopy after 24 and $48 \mathrm{~h}$ postinfection. We determined that there was a significant reduction in the number of intracellular Brucella for both time points at $41^{\circ} \mathrm{C}$ compared with that at $37^{\circ} \mathrm{C}$. On the other hand, even though B. abortus was viable up to $72 \mathrm{~h}$ incubation at $37^{\circ} \mathrm{C}$, infection and incubation of HD11 at this temperature did not sustain an increasing intracellular growth rate. This growth rate is not comparable to the steady growth observed in other primary mammalian cells such as RAW 264.7, reaching higher log rates and displaying a steady increased intracellular growth [27]. Additionally, cytokine expression of HD11, incubated at $37^{\circ} \mathrm{C}$ and $41^{\circ} \mathrm{C}$, was not affected by $B$. abortus infection, in contrast with responses in murine macrophages. Therefore, this bacterial growth inhibition might be attributed to other factors innate to this chicken macrophage, which may require further investigation.

Taken together, given the same intracellular load upon invasion for both $37^{\circ} \mathrm{C}$ and $41^{\circ} \mathrm{C}$, and higher bactericidal rate at $41^{\circ} \mathrm{C}$ along an increasing period of incubation compared with $37^{\circ} \mathrm{C}$, Brucella the higher temperature rendered less for intracellular replication, thus suppressing bacterial growth. This study also shows that despite incubation at an ambient temperature and initially having a higher number of intracellular Brucella, an increasing intracellular growth is still not attained in HD11. The results of this study give clearer understanding about the direct bactericidal effect of temperature as a major factor that might confer bacterial resistance to brucellosis in avian species.

\section{Acknowledgments}

This research was supported by a grant of the Korea Health Technology R\&D Project through the Korea Health Industry Development Institute (KHIDI), funded by the Ministry of Health \& Welfare, Republic of Korea (Grant No. HI16C2130).

\section{Conflict of Interest}

The authors have no financial conflicts of interest to declare.

\section{References}

1. Zekarias B, Ter Huurne AA, Landman WJ, Rebel JM, Pol JM, Gruys E. 2002. Immunological basis of differences in disease resistance in the chicken. Vet. Res. 33: 109-125.

2. Adams LG, Schutta C. 2010. Natural resistance against brucellosis: a review. Open Vet. Sci. J. 4: 61-71.

3. Chen P, Shakhnovich E. 2010. Thermal adaptation of viruses and bacteria. Biophys. J. 98: 1109-1118.

4. Butcher G, Miles R. 1991. The avian immune system. VM74. Available from http://edis.ifas.ufl.edu/pdffiles/VM/VM01600. pdf. Accessed 2015.

5. Gray D, Marais M, Maloney S. 2013. A review of the physiology of fever in birds. J. Comp. Physiol. B 183: 297-312.

6. Qureshi N, Perera PY, Shen J, Zhang G, Lenschat A, Splitter G, et al. 2003. The proteasome as a lipopolysaccharide-binding protein in macrophages: differential effects of proteasome inhibition on lipopolysaccharide-induced signaling events. J. Immunol. 171: 1515-1525.

7. Cullum A, Bennet A, Lenski R. 2001. Evolutionary adaptation 
to temperature. IX. Preadaptation to novel stressful environments of Escherichia coli adapted to high temperature. Evolution 55: 2194-2202.

8. Travisano M, Lenski R. 1996. Long term experimental evolution in E. coli. IV. Targets of selection and specificity of adaptation. Genetics 143: 15-26.

9. Beug H, Kirchbach A, Döderlein G, Conscience JF, Graf T. 1979. Chicken hematopoietic cells transformed by seven strains of defective avian leukemia viruses display three distinct phenotypes of differentiation. Cell 18: 375-390.

10. Lee JJ, Kim DH, Lee HJ, Min W, Rhee M, Kim S, et al. 2013. Phellinus baumii extract influences pathogenesis of Brucella abortus by disrupting the phagocytic and intracellular trafficking pathway. J. Appl. Microbiol. 114: 329-338.

11. Higa F, Kusano N, Tateyama M. 1998. Simplified quantitative assay system for measuring activities of drugs against intracellular Legionella pneumophila. J. Clin. Microbiol. 36: 1392-1398.

12. Lee JJ, Kim DH, Kim DG, Lee HJ, Min W, Rhee MH, et al. 2013. Toll-like receptor 4-linked Janus kinase 2 signaling contributes to internalization of Brucella abortus by macrophages. Infect. Immun. 81: 2448-2458.

13. Braukmann M, Methner U, Berndt A. 2015. Immune reaction and survivability of Salmonella Typhimurium and Salmonella Infantis is after infection of primary avian macrophages. PLoS One 10: e0122540.

14. Hong YH, Lillehoj HS, Lee SH, Dalloul RA, Lillehoj EP. 2006. Analysis of chicken cytokine and chemokine gene expression following Eimeria aceroulina and Eimeria tenella infections. Vet. Immunol. Immunopathol. 114: 209-223.

15. Kapczynski D, Jiang HJ, Kogut MH. 2014. Characterization of cytokine expression induced by avian influenza virus infection with real-time RT-PCR. Methods Mol. Biol. 1161: 217-233.

16. Livak KJ, Schmittgen TD. 2001. Analysis of relative gene expression data using real-time quantitative PCR and the $2^{-\Delta \Delta C t}$ method. Methods 25: 402-408.

17. Adamu NB, Adamu SG, Jajere MS. 2014. Serological survey of brucellosis in slaughtered local chickens, guinea fowls, ducks and turkey in North-Eastern Nigeria. Int. J. Poult. Sci. 13: $340-342$.

18. Detilleux DG, Cheville NF, Deyoe BL. 1997. Pathogenesis of Brucella abortus in chicken embryos. Vet. Pathol. 25: 138-146.

19. Abbas B, Talei A. 2010. Isolation, identification and biotyping of Brucella spp. from milk product of Basrah Province. Bas. J. Vet. Res. 9: 152-162.

20. Zeldovich KB, Chen P, Shakhnovich E. 2007. Protein stability imposes limits on organism complexicity and speed of molecular evolution. Proc. Natl. Acad. Sci. USA 104: 1615216157.

21. Dyson HJ, Wright PE. 2005. Intrinsically unstructured proteins and their functions. Nat. Rev. Mol. Cell Biol 6: 197-208.

22. Uversky VN. 2002. Natively unfolded proteins: a point where biology waits for physics. Protein Sci. 11: 739-756.

23. Bloom JD, Raval A, Wilke CO. 2007. Thermodynamics of neutral protein evolution. Genetics 175: 255-266.

24. Taverna DM, Goldstein RA. 2002. Why are proteins marginally stable? Proteins 46: 105-109.

25. Leuenberger P, Ganscha S, Kahraman A, Cappelletti V, Boersema PJ, von Mering C, et al. 2017. Cell-wide analysis of protein thermal unfolding reveals determinants of thermostability. Science 355: eaai7825.

26. Kim W, Jeong J, Park A, Kim S, Min W, Kim D, et al. 2014. Downregulation of chicken interleukin-17 receptor A during Eimeria infection. Infect. Immun. 82: 3845-3854.

27. Reyes AW, Arayan LT, Simborio HL, Hop HT, Min W, Lee HJ, et al. 2016. Dextran sulfate sodium upregulates MAPK signaling for the uptake and subsequent intracellular survival of Brucella abortus in murine macrophages. Microb. Pathog. 91: 68-73. 